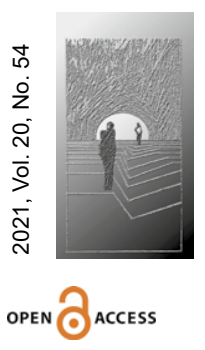

\title{
Wpływ doświadczeń teatralnych i predyspozycji scenicznych Karola Wojtyły na charakter publicznych wystąpień Jana Pawła II
}

\section{STRESZCZENIE}

CEL NAUKOWY: Celem artykułu jest ukazanie zależności pomiędzy doświadczeniami teatralnymi i predyspozycjami scenicznymi Karola Wojtyły a zachowaniem Jana Pawła II podczas jego publicznych wystąpień.

PROBLEM I METODY BADAWCZE: Poruszany w tekście problem koncentruje się wokół pytań: Czy doświadczenia teatralne i wybrane umiejętności Karola Wojtyły wywarły wpływ na charakter późniejszych publicznych wystąpień Jana Pawła II? Jeśli tak, jaki był ten wpływ? W czym się wyrażał? Metody wykorzystane do zbadania tego problemu to przegląd wybranej literatury oraz analiza nagrań wideo.

PROCES WYWODU: W pierwszej części przybliżona zostanie przeszłość teatralna Karola Wojtyły, głównie jego związki z Teatrem Rapsodycznym Mieczysława Kotlarczyka. W drugiej części na kilku przykładach zaprezentowane będą zachowania papieża podczas publicznych wystąpień. W trzeciej części zostanie pokazane, jaki wpływ na te zachowania miały predyspozycje sceniczne i doświadczenie aktorskie Jana Pawła II.

WYNIKI ANALIZY NAUKOWEJ: Z przeprowadzonej analizy wynika, że Jan Paweł II wykorzystywał zarówno zdobyte u Kotlarczyka doświadczenie teatralne, jak i wrodzone predyspozycje w swoich publicznych wystąpieniach. Posługiwał się nimi bardzo umiejętnie. Pomagały mu one budować mocniejszą więź ze swoimi odbiorcami, zjednywały sympatię, czyniły bardziej przekonującym. Sprawiały, że nie tylko treść jego homilii czy przemówień, ale także sposób ich wygłaszania przyciągał uwagę odbiorców.

WNIOSKI, INNOWACJE, REKOMENDACJE: Papież Polak miał bardzo wysoko rozwinięte kompetencje komunikacyjne, potrafił posługiwać się różnymi środkami wyrazu. Posiadał wrodzone umiejętności sceniczne, wykształcenie aktorskie i korzystał z tego również w swojej posłudze duszpasterskiej i kaznodziejskiej. Artykuł pokazuje wybrane zachowania papieskie podczas publicznych wystąpień, w których widać wpływ doświadczeń teatralnych. Można spróbować pod tym kątem przeanalizować dokładnie tylko jedną pielgrzymką albo - bardzo szczegółowo - jedno konkretne wystąpienie. Można także zwrócić uwagę na aspekt świadomego reżyserowania danego wystąpienia.

$\rightarrow$ SŁOWA KLUCZOWE: DOŚWIADCZENIE AKTORSKIE, JAN PAWEŁ II, KAROL WOJTYŁA, TEATR, PUBLICZNE WYSTĄPIENIA 


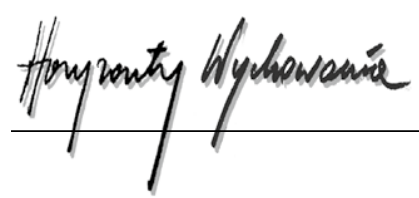

ABSTRACT

Influence of Karol Wojtyła's Theatrical Experiences and Acting Predispositions on the Character of John Paul II's Public Appearances

RESEARACH OBJECTIVE: The aim of the article is to show the relationship between Karol Wojtyła's theatrical experiences and his acting predispositions and the later behavior of John Paul II during his public appearances.

THE RESEARCH PROBLEM AND METHODS: The issue discussed in the text revolves around the following questions: Did Karol Wojtyła's theatrical experiences and his selected skills have an impact on the character of John Paul Il's later public appearances? If so, what was this impact? What was expressed in? The methods used to investigate the problem were: literature review and analysis of video recordings.

THE PROCESS OF ARGUMENTATION: The first part introduces Karol Wojtyła's theatrical past, focusing on his ties to Mieczysław Kotlarczyk's Rapsodic Theater. In the second part, the Pope's behavior during his public speeches is presented on a few examples. The third part shows the impact of John Paul Il's acting predispositions and acting experience on these behaviors.

RESEARCH RESULTS: The analysis shows that John Paul II used both his theatrical experience gained with Kotlarczyk and his inborn predispositions in his public appearances. He used them very skillfully. They helped him build a stronger bond with his audience, won him their affection and made him more convincing. They made the content of his homilies or speeches on top of the way they were delivered, attract the attention of the audience.

CONCLUSIONS, INNOVATIONS, AND RECOMMENDATION: The Polish Pope had highly developed communication skills, he was able to use various means of expression. He had innate acting skills and acting education, which he also used in his pastoral and preaching work. The article shows selected papal behaviors during his public speeches, in which the influence of his theatrical experiences can be seen. From this perspective, one may try to thoroughly analyze one pilgrimage only or - in great detail - one specific speech. One can also pay attention to the aspect of the Pope's consciously directing a given performance.

\section{$\rightarrow$ KEYWORDS: ACTING EXPERIENCE, JOHN PAUL II, KAROL WOJTYŁA, THEATER,} PUBLIC APPEARANCES

\section{Wprowadzenie}

Jan Paweł II już we wczesnej młodości interesował się teatrem. Posiadał wrodzony talent, dlatego szybko zaczął odgrywać role najpierw w teatrze szkolnym w Wadowicach, a później jako student w Krakowie. Teatr Rapsodyczny Mieczysława Kotlarczyka wywarł duży wpływ nie tylko na jego umiejętności, ale i wrażliwość artystyczną, formację duchową. Po wstąpieniu do seminarium Karol Wojtyła zrezygnował z tego typu działalności, 
ale w swoich późniejszych publicznych wystąpieniach, także jako papież, wykorzystywał zdobyte doświadczenie i własne predyspozycje. Po przybliżeniu teatralnej formacji Karola Wojtyły na wybranych przykładach pokażę, jak wyglądały zachowania Jana Pawła II podczas publicznych wystąpień, a następnie poszukam w tych zachowaniach wpływu jego doświadczeń teatralnych.

\section{Adept sztuki teatralnej ${ }^{1}$}

Punktem wyjścia dla każdego dobrego aktora są wrodzone predyspozycje, które potem w umiejętny sposób powinny być rozwijane. Wojtyła takie posiadał i zostały one zauważone już w czasach wadowickich. Jego przyjaciele z młodości podkreślali, że jako uczeń Państwowego Gimnazjum Męskiego im. Marcina Wadowity wyróżniał się warunkami głosowymi, sposobem interpretacji, rozległym oczytaniem, umiejętnością nawiązywania kontaktu z publicznością. Zadebiutował jako aktor w wieku 13 lat w spektaklu Sobótka, składającym się z ludowych piosenek oraz Pieśni świętojańskiej o Sobótce Jana Kochanowskiego. Później odegrał rolę m.in. Gucia w Ślubach panieńskich Aleksandra Fredry, Hajmona w Antygonie Sofoklesa i Kirkora w Balladynie Juliusza Słowackiego. Ten ostatni spektakl reżyserował Mieczysław Kotlarczyk, nauczyciel prywatnego gimnazjum w Wadowicach i założyciel Amatorskiego Teatru Powszechnego w tym mieście. Kotlarczyk okazał się bardzo ważną osobą w życiu Wojtyły. Wprowadził go w świat wielkiej literatury romantycznej i młodopolskiej, rozmawiał z nim godzinami na tematy literackie i teatralne, kształtował jego wrażliwość artystyczną. Ta znajomość, która z czasem przekształciła się w przyjaźń, była kontynuowana później w Krakowie. W latach szkolnych Wojtyła miał również możliwość poznać repertuar Teatru im. Juliusza Słowackiego w Krakowie dzięki akcji edukacyjnej dyrektora Juliusza Osterwy, który w godzinach przedpołudniowych prezentował młodzieży przyjeżdżającej m.in. z Wadowic przedstawienia z klasyki polskiej i obcej.

W 1938 r. Wojtyła rozpoczął studia polonistyczne na Uniwersytecie Jagiellońskim w Krakowie. Już na początku roku akademickiego dał się poznać jako poeta, wziął bowiem udział w wieczorze literackim, podczas którego osobiście interpretował swoje wiersze. Jego wcześniejsze zainteresowania literackie sprawiły, że uczestniczył w prowadzonym na UJ przez Władysława Dobrowolskiego „lektoracie żywego słowa”, włączył się także w prace „Studia 39”, szkoły dramatycznej prowadzonej przez Krakowską Konfraternię Teatralną. Wojtyła od stycznia 1939 r. odbywał w Konfraterni ćwiczenia sceniczne z zakresu emisji głosu, charakteryzacji i ruchu. Wziął udział w jedynym przedstawieniu, jakie zdołano wystawić - Kawalerze księżycowym Mariana Niżyńskiego na dziedzińcu Collegium Nowodworskiego. Wystąpił w roli jednego ze znaków zodiaku, Byka. Wybuch wojny przerwał aktorskie działania młodego studenta, ale nie jego zainteresowania teatralne. Wiele czasu poświęcał na samokształcenie.

\footnotetext{
${ }^{1}$ Określenie Stanisława Dziedzica.
} 


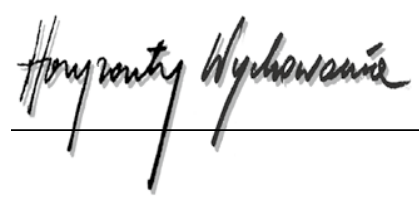

Początek wojny to również czas, kiedy przyszły papież podejmował pierwsze próby dramatopisarskie, pisał też wiersze. Od października 1939 r. wraz Tadeuszem Kwiatkowskim i Juliuszem Kydryńskim spotykał się w mieszkaniach zaprzyjaźnionych rodzin, aby czytać wielkie dzieła literatury polskiej z podziałem na role. Dołączyli do nich inni znajomi. Powstała w ten sposób nieformalna grupa teatralna prowadzona przez Tadeusza Kudlińskiego przygotowała inscenizację II aktu Przepióreczki Stefana Żeromskiego. Wojtyła poznał wtedy bliżej Juliusza Osterwę, który od razu zobaczył w nim materiał na bardzo dobrego aktora ${ }^{2}$.

Praca w Zakładach Chemicznych Solvay w Borku Fałęckim utrudniała młodemu artyście udział w spotkaniach teatralnych w mieszkaniu Kudlińskiego, ale wrócił do nich po krótkiej przerwie w październiku 1940 r. Zespół pracował wówczas nad rolami z II aktu Wesela Stanisława Wyspiańskiego, a później nad scenami z Wyzwolenia, w którym Wojtyła miał odgrywać rolę Konrada, do pokazu jednak nie doszło ${ }^{3}$.

W lipcu 1941 r. do Krakowa przyjechał Mieczysław Kotlarczyk. Zamieszkał u Wojtyły, przy ul. Tynieckiej 10. 22 sierpnia 1941 r. narodził się konspiracyjny teatr, nazwany później Teatrem Rapsodycznym. Stał się on jednym z ważniejszych elementów życia kulturalnego w wojennym i powojennym Krakowie. Jego historia była trudna, dwa razy go zamykano, Kotlarczyk borykał się z problemami związanymi ze sceną, repertuarem, zespołem. Nas jednak interesuje pierwszy okres działalności Teatru Rapsodycznego, łączący się bezpośrednio z osobą Wojtyły. Uczestniczył on w realizacji Króla-Ducha Juliusza Słowackiego (od rapsodów z Króla-Ducha teatr wziął swoją nazwę). Odegrał rolę Bolesława Śmiałego. Występująca razem z nim Danuta Michałowska wspominała, że podczas prapremiery Wojtyła wyróżniał się niezwykłą ekspresją, pełnym zaangażowaniem, że jego wykonanie było pełne dynamiki i napięcia. Podczas kolejnego wykonania, po dwóch tygodniach, jego interpretacja monologu króla zmieniła się nie do poznania, brzmiała - według słów Michałowskiej - jak spowiedź. W ciągu tych dwóch tygodni dzielących oba przedstawienia w Wojtyle „dojrzało myślenie kategoriami wyższej sztuki” (Michałowska, 2008, s. 97). Warto dodać, że był to czas w życiu przyszłego papieża, kiedy kształtowało się jego powołanie do kapłaństwa. Jacek Popiel zwraca uwagę na pogłębiony wymiar tej historii, która ujawnia zmiany zachodzące w świadomości religijnej młodego aktora. „Artyście interpretującemu ukazaną w dziele sztuki historię Bolesława Śmiałego przychodzi w sukurs kapłan, który próbuje głębiej i pełniej zrozumieć dramat człowieka" (Popiel, 2006, s. 274).

Wojtyła intensywnie brał udział w dalszych projektach artystycznych zespołu. W rapsodycznej wersji Beniowskiego mówił m.in. tzw. apostrofę do Ludwiki Śniadeckiej. Występował również w realizacji Hymnów Jana Kasprowicza, uznanej za jedno z najważniejszych zarówno od strony ideowej, jak i artystycznej osiągnięć teatru z czasów okupacji.

2 T. Kwiatkowski w książce Młodzieńcze lata Karola Wojtyły przytacza słowa Osterwy na temat Wojtyły: „Zapowiada się nadzwyczajny aktor” (cyt. za: Dziedzic, 2008, s. 72). Osterwy.

${ }^{3}$ Zespół zaczął wówczas pracować nad misterium Oskara Miłosza pod kierunkiem Juliusza 
W finale spektaklu interpretował samodzielnie Hymn św. Franciszka, był również osobą prowadzącą w zbiorowej recytacji hymnu Święty Boże. Występował także w kolejnych inscenizacjach: w Godzinie S. Wyspiańskiego i Portrecie artysty C.K. Norwida.

W październiku 1942 r. Wojtyła rozpoczął studia na Wydziale Teologicznym UJ jako kleryk konspiracyjnego Seminarium Archidiecezji Krakowskiej. Nadal brał udział w próbach zespołu, podczas premiery Pana Tadeusza interpretował partię księdza Robaka. W Samuelu Zborowskim wcielił się w tytułową rolę (premiera 16 marca 1943 r.). W połowie 1943 r. Wojtyła przestał uczestniczyć w pracach Teatru Rapsodycznego ${ }^{4}$. Nadal jednak interesował się dalszymi dokonaniami i losami zespołu, pozostawał w przyjacielskich relacjach z kolegami aktorami. Oglądał ich powojenne przedstawienia, odprawiał w ich intencjach msze św. Jako wikariusz w kościele św. Floriana w Krakowie odwiedzał ich w siedzibie teatru przy ul. Warszawskiej 5. Nie zaprzestał też zupełnie działań teatralnych, choć zmienił się ich charakter. Jako duszpasterz przygotowywał misterium Męki Pańskiej, organizował nabożeństwa, podczas których fragmenty Pisma Świętego oraz teksty poetyckie czytali i śpiewali m.in. aktorzy Teatru Rapsodycznego. Pisał również recenzje z niektórych premier zespołu. Pod pseudonimem Andrzej Jawień opublikował w „Tygodniku Powszechnym” artykuł Dramat słowa i gestu, w którym przypomniał zasługi rapsodyków i podkreślił konieczność stworzenia Kotlarczykowi dobrych warunków do pracy artystycznej. Swoje związki z teatrem podkreślał m.in. przy okazji spotkań z kolegami aktorami, do swoich ról teatralnych nawiązywał także jako papież, np. podczas spotkania z wiernymi na rynku w Wadowicach 7 czerwca 1979 r.

\section{Zachowania Jana Pawła II podczas publicznych wystąpień}

Jan Paweł II podczas swoich publicznych wystąpień, oprócz treści wygłaszanych homilii i przemówień, zwracał uwagę przede wszystkim głosem, gestykulacją, umiejętnością wykorzystywania różnych przedmiotów, dopasowywania się do zewnętrznych okoliczności, w których przemawiał (np. miejsca, pogody itp.), a także pewnością w sposobie bycia, reagowania na zachowania tłumu. Trzeba zaznaczyć, że najlepiej było to widoczne w pierwszych latach jego pontyfikatu, kiedy był jeszcze młody, zdrowy, silny, nie borykał się z fizycznymi ograniczeniami, w pełni panował nad swoim ciałem. Poniższe spostrzeżenia odnoszą się do tego właśnie okresu.

Pierwszym elementem, na który trzeba zwrócić uwagę, jest głos Jana Pawła II. Był to głos mocny, wyraźny, dźwięczny, dobrze brzmiący, o bardzo przyjemnej barwie. Tym głosem już od młodości przyciągał uwagę swoich słuchaczy. Tak pisze o nim D. Michałowska:

Wreszcie głos: o szczególnie pięknej barwie, ciepły, miękki, niezbyt niski, wyrażający jakąś niepowtarzalną, jego własną, jemu tylko właściwą intymność; zarazem nośny i dźwięczny,

${ }^{4}$ Z ustaleń J. Popiela wynika, że Wojtyła wziął udział jako aktor w sześciu premierach Teatru Rapsodycznego (Popiel, 2006, s. 279). 


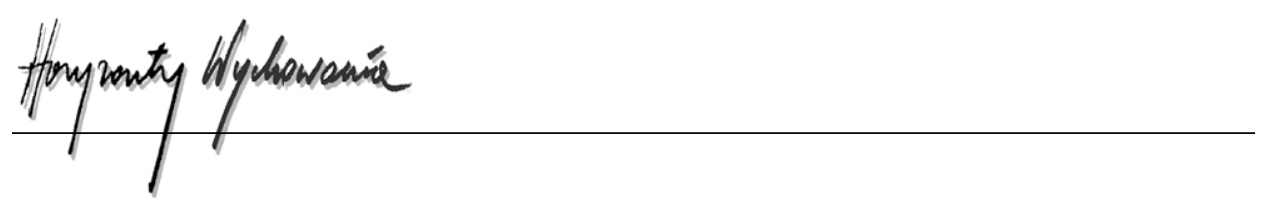

doskonale słyszalny, już wtedy [w czasach Teatru Rapsodycznego - M.J.] przeznaczony do rozbrzmiewania na wielkich placach, gigantycznych stadionach, na płytach lotnisk i pod kopułami najwspanialszych bazylik wszystkich kontynentów ziemi (cyt. za: Dziedzic, 2008, s. 86).

Papież wyraźnie akcentował poszczególne słowa. Umiejętnie posługiwał się pauzą, intonacją, emfazą. Nie recytował, nie deklamował, nie mówił z patosem, ale z wielkim spokojem, wręcz namaszczeniem ${ }^{5}$. Takie cechy jego głosu ujawniały się przede wszystkim w wygłaszanych przez niego homiliach. Rzadko głos podnosił, na ogół słychać było w nim opanowanie. Gdy przemawiał podczas spotkań o mniej oficjalnym charakterze, w głosie jego pojawiało się więcej spontaniczności, często dominował ton żartobliwy. Jan Paweł II wykorzystywał też inny atut swojego głosu: jego melodyjność, łączącą się z dobrym słuchem. Papież potrafił śpiewać. Robił to czysto, pewnie. Mógł sobie pozwalać na różne wariacje w tym zakresie (np. śpiew drugim głosem). Doświadczyli tego też uczestnicy spotkań na krakowskiej Skałce (8 czerwca 1979 r.) czy pod papieskim oknem (np. w dniach 6-9 czerwca 1979 r.).

W nagraniach wideo z publicznych wystąpień Jana Pawła II zwraca uwagę również jego gestykulacja. Była ona dość zróżnicowana. Wygłaszając homilie, papież rzadko wykonywał gesty. Jeśli już się pojawiały, były one bezpośrednio związane z tokiem narracji, służyły podkreśleniu konkretnych treści, zaakcentowaniu ich. Najczęściej wykonywanym przez niego rodzajem gestów były tzw. gesty batutowe, polegające na rytmicznym podnoszeniu i opuszczeniu ręki, towarzyszące słowom o szczególnym znaczeniu. Ponieważ papież na ogół trzymał kartki z treścią homilii, gestykulował tylko jedną ręką albo potrząsał tymi kartkami, podnosił je. Ograniczał się do gestów batutowych, ściśle związanych z tokiem narracji, podkreślających wypowiadane słowa i pełniących funkcję perswazyjną. Oszczędność i umiarkowanie w stosowaniu gestów widać wyraźnie w nagraniu z homilii wygłoszonej 7 czerwca 1979 r. w Oświęcimiu podczas I pielgrzymki do Polski. W trwającej ponad 45 minut homilii pojawia się tylko kilka gestów, powtarzających się, o typowo narracyjnym charakterze. Inaczej jednak wyglądała gestykulacja Jana Pawła II podczas spotkań mniej oficjalnych poza kontekstem liturgicznym. Cechowała ją wówczas duża ekspresja, swoboda i różnorodność. Gesty papieża stawały się bardziej wyraziste, często miały charakter ilustracyjny, dookreślały znaczenia, stawały się źródłem dodatkowych informacji dzięki temu, że papież wykonywał je precyzyjnie i z dużym wyczuciem (Jankosz, 2019). Podczas przemówienia skierowanego do młodzieży zgromadzonej na Wzgórzu Lecha w Gnieźnie w 1979 r. papież imitował gestami

${ }^{5}$ Słychać to $\mathrm{np}$. w homilii wygłoszonej na krakowskich Błoniach podczas I pielgrzymki do Polski we fragmencie: „I dlatego - zanim stąd odejdę, proszę was, abyście całe to duchowe dziedzictwo, któremu na imię "Polska», raz jeszcze przyjęli z wiarą, nadzieją i miłością - taką, jaką zaszczepia w nas Chrystus na chrzcie świętym - abyście nigdy nie zwątpili i nie znużyli się, i nie zniechęcili, abyście nie podcinali sami tych korzeni, z których wyrastamy” (Jan Paweł II, 2012, s. 205). Szczególnie zwraca tu uwagę sposób, w jaki Jan Paweł II wypowiada triadę „wiara, nadzieja i miłość” robi to powoli, wyraźnie akcentuje każde słowo. 
np. rozpalanie ogniska, nakręcanie zegarka (Jankosz, 2018b). Dobrze znane są także papieskie gesty wykonywane już bez związku z wygłaszanym tekstem. Papieska ręka podniesiona w górę w geście błogosławieństwa, szeroko otwarte, podniesione do góry ręce papieża wysiadającego z samolotu, ucałowanie ziemi w pozycji klęczącej - te gesty nabrały znaczenia symbolicznego, jednoznacznie kojarzą się z Janem Pawłem II.

Oglądając nagrania z czasów wczesnego pontyfikatu Jana Pawła II, możemy też zauważyć, że chętnie sięgał on po różne przedmioty, wykorzystywał je podczas spotkań z wiernymi. Zakładał podarowane mu regionalne nakrycia głowy czy inne elementy garderoby, wzbudzając tym samym entuzjazm tłumu, wykorzystywał swój płaszcz do zabawy z dzieckiem. Nawet w podeszłym wieku, kiedy musiał już wspomagać się laską przy poruszaniu, wykorzystywał tę laskę, machając nią, dyrygując za jej pomocą tłumem, aby równo śpiewał ${ }^{6}$. W ten sposób prowokował też różne reakcje swoich odbiorców.

Papież, przemawiając publicznie, często nawiązywał do elementów otoczenia, w którym się znajdował, do warunków atmosferycznych, dekoracji ołtarza, do zabytków danego miejsca, cech krajobrazu. W jego wypowiedziach w Warszawie odnajdziemy odwołania do Grobu Nieznanego Żołnierza ${ }^{7}$, w Gnieźnie do Wzgórza Lecha ${ }^{8}$, w Zakopanem do krzyża na Giewoncie ${ }^{9}$, w Gdańsku - do Bałtyku ${ }^{10}$. W nawiązaniach tych papież posługiwał się również niekiedy gestami deiktycznymi (wskazującymi).

Oprócz głosu, gestu, wykorzystywanych przedmiotów i odniesień do elementów otoczenia w publicznych wystąpieniach Jana Pawła II zwraca też uwagę duża swoboda w jego zachowaniach. Prawie nigdy nie ograniczał się do odczytywania tekstu, uzupełniał go różnymi dygresjami, szybko ustosunkowywał się do reakcji odbiorców. Papież panował nad reakcjami tłumu, odpowiednio nimi kierował. Na Franciszkańskiej 3 w Krakowie pełnił niekiedy funkcję wodzireja, zachęcającego tłum do różnych aktywności. Tak było np. podczas I pielgrzymki do Polski, kiedy mobilizował zebranych do odśpiewywania kolejnych zwrotek Barki. Potrafił też odpowiednio reagować na oklaski. Czasami dostosowywał do nich jakąś część swoich wypowiedzi (np. podczas spotkania z młodzieżą przed kościołem św. Anny 3 czerwca 1979 r., gdy mówił o tym, że oklaski wskazują mu fragmenty najważniejsze dla

${ }^{6}$ „Pamiętam, to było w Manili, na Filipinach. Papież posługiwał się już laską - i nie tylko nie pozwalał jej ukryć (...), ale zaczął nią nawet wywijać jak Charlie Chaplin, wywołując ogromną radość zgromadzonych (...). Przyznaję, że owa laska w jego ręku przemawia do mnie silniej niż tom przemówień" (Poniewierski, 2006, s. 80).

7 „Stoimy tutaj w pobliżu Grobu Nieznanego Żołnierza” (Jan Paweł II, 2012, s. 24).

8 „Ile wieków liczy ta mowa Ducha Świętego, którą on dzisiaj sam przemawia i z watykańskiego wzgórza świętego Piotra, i tutaj w Gnieźnie ze Wzgórza Lecha” (Jan Paweł II, 2012, s. 37).

9 „I kiedy kończył się wiek XIX, a rozpoczynał współczesny, ojcowie wasi na szczycie Giewontu ustawili krzyż. Ten krzyż tam stoi i trwa" (Jan Paweł II, 2012, s. 950).

10 „Gdańsk, który - wśród zmiennych kolei dziejowych - trwał stale przy ujściu Wisły, rzeki polskich ziem. I stale tu, nad brzegiem Bałtyku, otwierał przed nami te perspektywy, jakie ukazuje człowiekowi na ziemi: morze. Perspektywy dali bezbrzeżnej, perspektywy głębi swoich wód, perspektywy wolności” (Jan Paweł II, 2012, s. 490). 


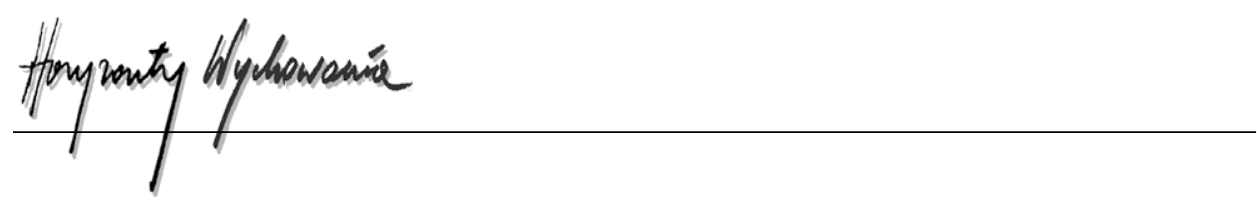

odbiorców), a czasami, podczas spotkań nieoficjalnych, wręcz je prowokował (np. podczas spotkania z młodzieżą na Wzgórzu Lecha 3 czerwca 1979 r.).

\section{Doświadczenie aktorskie i świadomość teatralna a publiczne wystąpienia Jana Pawła II}

Przyglądając się wybranym zachowaniom Jana Pawła II podczas jego publicznych wystąpień, można w nich odnaleźć zdobyte przez niego umiejętności i wrodzony talent sceniczny.

Przyszły papież w młodości miał możliwość pracować nad swoim głosem, uczył się nad nim panować, nadawać mu odpowiednie brzmienie, przekazywać za jego pomocą przeżycia wewnętrzne. To jedna z podstawowych umiejętności każdego aktora. Teatr Rapsodyczny, któremu swoją formację aktorską i artystyczną zawdzięcza Jan Paweł II, kładł nacisk na specjalny sposób wypowiadania, w którym ważną rolę odgrywała dykcja, intonacja, pauza, rytm, barwa, dynamika, frazowanie. Mieczysław Kotlarczyk wymagał od swoich aktorów takiego mówienia, które różni się od zwykłego „o całą dziedzinę własnej techniki, artyzmu i kultury" (Kotlarczyk, 1975, s. 22). Nazywał je mówieniem artystycznym. Tak właśnie można określić sposób artykułowania homilii przez Jana Pawła II. Papież potrafił tonem głosu skierować uwagę odbiorców na treść wypowiadanych słów, podkreślić ich znaczenie, interpretować je. Wyraźnie słychać to w homilii wygłoszonej na pl. Zwycięstwa w Warszawie (por. Jankosz i Przyczyna, 2020). Pewność w głosie, którą słychać z kolei podczas spotkań nieoficjalnych, a także umiejętność śpiewu wynikały z wrodzonych predyspozycji papieża, z jego talentu, a także obycia scenicznego, wielu okazji do publicznych wystąpień, które miał, zanim jeszcze został księdzem.

Wpływ doświadczeń teatralnych można dostrzec też w typie gestykulacji Jana Pawła II. Na opisaną wcześniej jej oszczędność w sytuacjach oficjalnych miało wpływ kilka czynników: po pierwsze, ograniczenia tych właśnie sytuacji, które dość ściśle regulują charakter gestykulacji (Jankosz, 2018a), po drugie, wspomniana konieczność trzymania kartek z tekstem w dłoniach, co znacznie redukowało możliwość wykonywania gestów. Wydaje się jednak również, że taki właśnie rodzaj ekspresji - bardzo ascetyczny - był także elementem doświadczenia aktorskiego wyniesionego z Teatru Rapsodycznego. Gest miał nie zasłaniać słowa, ale pomagać wydobywać jego znaczenie. Najważniejsze zaś było, aby maksymalnie ograniczać środki ekspresji, aby na pierwszym planie było słowo - tej zasadzie Jan Paweł II był wierny jako homilista. Redukcja gestów w Teatrze Rapsodycznym była pod wieloma względami sprzeczna z naturą, większość mówców używa gestykulacji, aby wspomagać swój tok narracji (dotyczy to zwłaszcza wystąpień o charakterze spontanicznym). Rapsodycy byli jednak wierni zasadzie, że najważniejsze słowa nie wymagają wsparcia gestami.

O tym jednak, że Jan Paweł II miał dużą swobodę wykonywania gestów, świadczą jego publiczne wystąpienia poza kontekstem liturgicznym. W nich ujawnia się już nie tyle konkretna formacja aktorska, ile pewne predyspozycje. Kiedy naśladował gestem jakąś 
czynność, była ona łatwa do zinterpretowania. Potrafił za pomocą gestów oddać własne emocje: radość (poprzez podniesienie rąk), wzruszenie (poprzez przyłożenie dłoni do serca). Wykorzystywał gestykulację w żartach, udając niekiedy zawstydzenie czy zniechęcenie lub przyganę (machnięcia ręką, grożenia palcem; te zachowania są bardzo dobrze widoczne w nagraniu ze wspomnianego już spotkania z młodzieżą na Wzgórzu Lecha). Na szczególną uwagę zasługuje wspomniany gest Jana Pawła II, powtarzany (dopóki pozwalało na to zdrowie) podczas każdej jego pielgrzymki - ucałowanie ziemi w pozycji klęczącej podczas powitania kolejnego kraju na lotnisku. Miał on w sobie duży ładunek dramatyczny, był bardzo sugestywny i poruszający. Gest ten nie był elementem gry aktorskiej, trzeba jednak zauważyć, że świadomość roli gestu, jaką posiada dobry aktor, z pewnością pomogła papieżowi sięgnąć po zachowanie tak wyraziste.

Różne przedmioty, elementy garderoby stawały się w rękach papieża rekwizytami. Rekwizyty w teatrze są odpowiedzialne za kreowanie rzeczywistości, warunkują właściwy odbiór sztuki, nadają klimat. Pomagają w tworzeniu relacji bohater - otoczenie. Meksykański kapelusz na głowie papieża pełnił taką właśnie funkcję - budował relację, przełamywał dystans, kreował sytuację spontaniczną, bezpośrednią, nieco żartobliwą, sympatyczną. To, że papież umiał i chciał wykorzystywać różne przedmioty podczas swoich publicznych wystąpień, świadczy również o fakcie, że był świadomy roli rekwizytu, który staje się dodatkowym środkiem wyrazu i również dookreśla albo zastępuje treści należące do warstwy werbalnej.

Nawiązania do miejsca i okoliczności wygłaszania przemówienia, pojawiające się podczas wielu publicznych wystąpień Jana Pawła II, pokazują, że papież traktował je jak elementy scenografii. Wacław Oszajca zwrócił uwagę na wrażliwość Jana Pawła II na taką scenografię, zdecydowanie łączącą się według niego z edukacją teatralną. „Pamiętam jego wizytę w Kielcach, kiedy zaczął mówić o obronie życia, o aborcji i podjął tematy bardzo ciężkie i wtedy zaczęła zbliżać się burza” - wspominał w audycji „Notatnik Dwójki”. „Zerwał się wiatr, niebo zrobiło się potwornie czarne. Sama natura stworzyła mu scenografię i on od razu wszedł w ten nastrój. Człowiek, który jest niewyczulony na teatr, nie wszedłby tak ładnie w to, co mu przynosi chwila" (Jan Paweł II - urodzony aktor, 2013). Jako dobry mówca i człowiek z dużą wiedzą o tym, jak działa teatr, wiedział, że opisując pewne treści i ilustrując je nawiązaniem do elementów wizualnych, na które może skierować wzrok swoich odbiorców, staje się bardziej sugestywny i przekonujący. Nie jest też przypadkiem, że dekorację ołtarzy, na których wygłaszał homilie i odprawiał msze św. Jan Paweł II, przygotowywali niekiedy wybitni teatralni scenografowie (np. Marian Kołodziej w Gdańsku w 1987 r. czy w Sopocie w 1999 r.).

Nieobca była papieżowi także sztuka improwizacji. Nawet wtedy, kiedy odczytywał wcześniej przygotowane słowa, nie miał żadnych problemów z tym, aby nie ograniczać się do zapisanego tekstu. Niektóre spotkania były w całości improwizowane, przede wszystkim te o nieoficjalnym charakterze. Ta umiejętność improwizacji również wiąże się z doświadczeniem teatralnym i wrodzonym talentem Jana Pawła II.

Wpływ doświadczeń teatralnych na zachowania Jana Pawła II ujawnia się także w jego reakcji na oklaski. One go nie peszyły, nie wytrącały go z toku narracji. Pewnie 


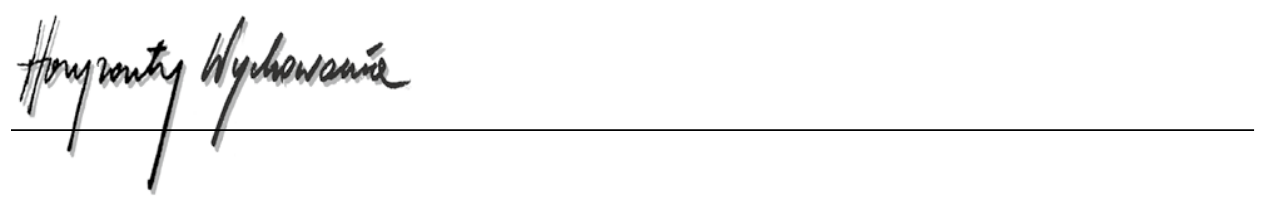

niekiedy przeszkadzały, wspominał zresztą o tym w swoich wypowiedziach, ale miał świadomość, że są ważnym elementem publicznego wystąpienia, że pozwalają odbiorcom nawiązać w ten sposób dialog, wyrazić emocje, że są potrzebne. Poza tym w młodości jako aktor, recytator był do nich przyzwyczajony.

\section{Podsumowanie}

Teatr wywarł duży wpływ na biografię, wrażliwość artystyczną i umiejętności Jana Pawła II, a także na charakter jego pontyfikatu. Jak to ujmuje Kosiński:

(...) pontyfikat Jana Pawła II był jak żaden dotąd dramatyczny i teatralny. Liczba wystąpień i podróży, które przecież były świadomie skonstruowanymi dramatyzacjami i przedstawieniami, pokazuje, że szczególną troską Jana Pawła II było tworzenie sceny, na której mógł być widziany, z której mógł być słuchany i słyszany. Jego liczne wystąpienia były w dosłownym znaczeniu aktami wstąpienia na scenę, wejścia w przestrzeń wzroku i słuchu innych $(2008$, s. 5).

Papież bardzo umiejętnie wykorzystywał swój talent i doświadczenie. Dzięki temu nie tylko treść jego homilii czy przemówień, ale także sposób ich wykonywania wywierały duży wpływ na słuchaczy. Przytoczony wyżej badacz uznał wręcz, że siła oddziaływania papieża brała się przede wszystkim nie z treści, ale z jakości jego publicznej działalności. Porywał on za sobą tłumy m.in. dzięki temu, że jego świadectwo miało kompozycję dramatu, którego był „autorem, reżyserem i jedynym aktorem” (Kosiński, 2008, s. 1).

Jan Paweł II nauczył się w młodości panować nad swoim głosem, nadawać swoim gestom znaczenie symboliczne, przedmiot w jego rękach stawał się rekwizytem, swoje otoczenie traktował jako scenografię. Jako Karol Wojtyła zdobył narzędzia, które później pomagały mu być bardziej przekonującym, lepiej trafiać do odbiorców, budować z nimi więź.

\section{BIBLIOGRAFIA}

Borowski, A. (2014). Jan Paweł II i retoryka. W: M. Jačov, F. Ziejka i W. Zuziak (red.). Przesłanie Jana Pawła II na XXI wiek (s. 99-106). Kraków: Wydawnictwo Naukowe Uniwersytetu Papieskiego Jana Pawła II.

Dziedzic, S. (2008). Adept sztuki teatralnej. W: K. Flader i W. Kawecki (red.), Jan Paweł Il człowiek kultury (s. 71-90). Kraków: Dom Wydawniczy Rafael.

Jan Paweł II. (2012). Pielgrzymki do ojczyzny. Przemówienia, homilie. Kraków: Znak.

Jankosz, M. (2018a). Sytuacje komunikacyjne publicznych wystąpień Jana Pawła Il podczas I pielgrzymki do Polski. Polonia Sacra, 50(1), 183-194.

Jankosz, M. (2018b). Wpływ sytuacji komunikacyjnej na zachowania Jana Pawła II podczas spotkania z młodzieżą na Wzgórzu Lecha w 1979 roku. Poznańskie Spotkania Językoznawcze, 35-36, 23-32.

Jankosz, M. (2019). Gesty narracyjne Jana Pawła II. Horyzonty Wychowania, 18(45), 121-131. 
Jankosz, M. i Przyczyna, W. (2020). Rapsodyk na ambonie? Jan Paweł II na placu Zwycięstwa w Warszawie w świetle założeń Teatru Rapsodycznego Mieczysława Kotlarczyka. Roczniki Humanistyczne, 68, 249-261.

Kosiński, D. (2008). Performer. Jan Paweł II i polski teatr przemiany. Więź, 10. http://wiez.pl/laboratorium/teksty.php?_performer_jan_pawel_ii_i_polski_teatr_przemiany\&p=1

Kotlarczyk, M. (1975). Sztuka żywego słowa. Rzym: Fundacja Teatru Religijnego i Przyjaciół Teatru Rapsodycznego.

Michałowska, D. (2008). Aktor. W: K. Flader i W. Kawecki (red.), Jan Paweł Il człowiek kultury (s. 91-100). Kraków: Dom Wydawniczy Rafael.

Jan Paweł II - urodzony aktor (2013). [Audycja radiowa]. https://www.polskieradio.pl/8/1594/ Artykul/957402,Jan-Pawel-II-urodzony-aktor

Poniewierski, J. (2006). Gesty Jana Pawła II. Kraków: Znak.

Popiel, J. (2006). Los artysty w czasach zniewolenia. Kraków: Wydawnictwo Uniwersytetu Jagiellońskiego.

Popiel, J. (2014). Karol Wojtyła w świecie teatru. W: M. Jačov, F. Ziejka i W. Zuziak (red.). Przesłanie Jana Pawła II na XXI wiek (s. 123-137). Kraków: Wydawnictwo Naukowe Uniwersytetu Papieskiego Jana Pawła II.

Słownik wiedzy o teatrze. (2005). Bielsko-Biała: ParkEdukacja.

\section{Copyright and License}

This article is published under the terms of the Creative Commons Attribution - NoDerivs (CC BY- ND 4.0) License http://creativecommons.org/licenses/by-nd/4.0/ 